\title{
TANGIBLE JOURNAL
}

https://ojs.stie-tdn.ac.id/index.php/TB

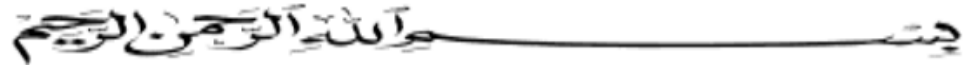

Dengan Menyebut Nama Allah Yang Maha Pengasih Lagi Maha Penyayang

Effective From Volume 5, No. 2, 2020

\section{FACTORS AFFECTING ENTREPRENEURIAL INTENTIONS AMONG COLLEGE STUDENT}

\author{
Trisna Sary Lewaru ${ }^{1}$ dan Fanny M. Anakotta ${ }^{2}$ \\ 12 Bussines and Economic Faculty Pattimura University, Ambon, \\ Maluku Province, Indonesia \\ eka_lewa@yahoo.com
}

\begin{abstract}
ABSTRAK
Penelitian ini bertujuan untuk menganalisis faktor-faktor yang mempengaruhi niat berwirausaha di kalangan mahasiswa. Lima variabel independen yang digunakan meliputi kebutuhan berprestasi, locus of control, self-efficacy, kesiapan instrumental, dan pengalaman kewirausahaan. Penelitian ini menggunakan metode kuantitatif dan sampel dalam penelitian ini adalah 160 mahasiswa Universitas Pattimura. Analisis regresi linier berganda digunakan untuk mengukur penelitian ini. Hasil penelitian ini menunjukkan bahwa kebutuhan berprestasi, locus of control, pengalaman berwirausaha tidak berpengaruh terhadap niat berwirausaha di kalangan mahasiswa sedangkan variabel kesiapan instrumental dan efikasi diri berpengaruh positif dan signifikan terhadap niat berwirausaha mahasiswa Universitas Pattimura.
\end{abstract}

\section{ABSTRACT}

This study aims to analyze the factors that influence entrepreneurial intentions among students. The five independent variables used include need for achievement, locus of control, self-efficacy, instrumental readiness, and entrepreneurial experience. This study used quantitative methods and the sample in this study were 160 students at Pattimura University. Multiple linear regression analysis was used to measure this study. The results of this study indicate that the need for achievement, locus of control, entrepreneurial experience has no effect on entrepreneurial intentions among students. Meanwhile, the variables of instrumental readiness and self-efficacy have a positive and Volume 5 Nomor 2 Halaman 79-86 Makassar, Desember 2020 p-ISSN 2528-3073 e-ISSN 24656-4505

Tanggal masuk 21 November 2020 Tanggal Revisi 23 November 2020 Tanggal diterima 25 Januari 2021

Similarity Found: 9\% Statistics: 306 words Plagiarized/3245 Total words

Kata Kunci: Kewirausahaan, Niat, Locus Of Control

Keywords :

Entrepreneurship

Intentions, dan Locus of Control 


\section{Introduction}

The success stories of young entrepreneurs who have successfully built and developed their businesses have given a lot of inspiration. As the story of Reza Nurhilman a young man who is now a hot conversation in cyberspace and fame among young people, has successful to build a business cassava chips "Setan" Maicih. In addition to Reza, the young man who success to become the richest youth is Mark Zuckerberg, the founder of Facebook that makes success to collect wealth up to Rp.13, 5 bilyun. What a remarkable achievement. And many more success stories of other young people who can be used as a lesson and motivation to build success. Actually young age is not an obstacle to the success of an entrepreneur. Today there are many opportunities to become entrepreneurs. In the educational environment, programs to develop student entrepreneurship have been implemented. Examples such as entrepreneurship programs, student creativity programs (PKM), and others.

These programs are created so that students with creative ideas can be helped in running and developing the idea. Most of the drivers of change, innovation, and progress in our economy come from entrepreneurs; The people who have the ability to take risks and accelerate economic growth. And now there are many opportunities for entrepreneurship. Therefore based on regulations no. 12 year 2012 adds entrepreneurship as a general basic subject known as MKDU (general education). The course is held in order to create new entrepreneur from college graduate (DITJEN Higher Education, 2013). Ciputra (2009) argued that entrepreneurship is the right solution to solve the problem of unemployment and poverty in Indonesia, because by only armed with a qualification without the skills of entrepreneurship then prepare yourself to queue up work because the current supply of college graduate workforce is not proportional to the available job opportunities. Growing the entrepreneurial spirit of college students is believed to be an alternative way to reduce unemployment, because scholars are expected to become young educated entrepreneurs who can pioneer their own business (Suharti and Sirine, 2011).

The influence of entrepreneurship education has been considered as an important factor to develop entrepreneurial passion, entrepreneurship behavior among the younger generation (Kourilsky and Walstad, 1998). Associated with the influence of entrepreneurship education, it is necessary to have an understanding of how to develop and encourage the birth of potential young entrepreneurs while they are in college. Several previous studies have suggested that the entrepreneurship desire of the students is a source for the birth of future entrepreneurs (Gorman et al., 1997; Kourilsky and Walstad, 1998). Their attitudes, attitudes and knowledge of entrepreneurship will shape their tendency to open up new business in the future. According to Hisrich et al. (In Caecilia, 2012), the intention relates to an indication of how difficult a person tries to understand, how much effort a person in planning something, to perform a certain behavior.

The number of entrepreneurs in Maluku is very small compared to the number of entrepreneurs in other regions in Indonesia. Though the growth and economic development today is very competitive that requires a high skill and creativity. To be able to compete, universities must be able to develop their human resources in this case students to become entrepreneurs and able to create jobs for themselves and others. The question is what is the factors that affect the student's sense of interest?. According to research conducted by Nurul and Sambharakreshna (2015) on factors influencing entrepreneurial intentions including achievement needs, locus of control, self efficacy, instrument readiness and dummy variables consisting of gender (D1), ethnicity (D2), experience (D3), and parent background (D4). While the research conducted by Indarti (2004) uses four variables to predict the intentions of entrepreneurship, namely the need for achievement, locus of control, self-efficacy, and instrumental readiness. Based on the description above, the authors are interested to choose the title "factors that influence entrepreneurial intentions among college student"

\section{Research Hypothesis}

Referring to the research of Indarti (2004), Herawati at all (2015), this research uses five indicators: Need for achievement, Locus of control, Self efficacy, Readiness of instruments, and 
TANGIBLE : JURNAL AKUNTANSI MULTIPARADIGMA VOL. 5 (2), HAL. 79-86

entrepreneurial experience. These five indicators are the factors that will be assessed whether they have an impact on the entrepreneurial intent of the college students of Pattimura University. For that hypothesis to be tested is as follows:

H1: Need for achievement is a significant predictor of entrepreneurial intentions.

H2: Locus of control is a significant predictor of entrepreneurial intentions.

H3: Self-efficacy is a significant predictor of entrepreneurial intentions.

H4: Instrumental readiness is a significant predictor of entrepreneurial intentions.

H5: Entrepreneurship experience is a significant predictor of entrepreneurial intentions.

The framework of thought in this study can be seen in Figure 1, as follows:

Figure 1. The Model Used In The Research

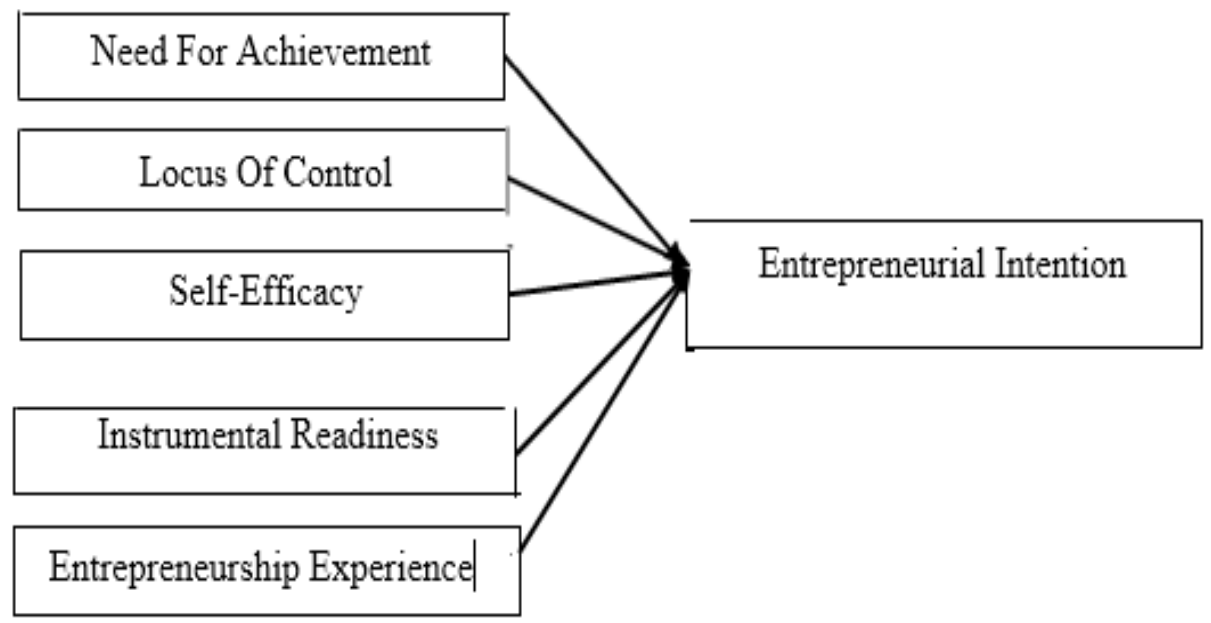

Source: Researcher (2017)

\section{Research Methodology}

This research uses quantitative methods and samples of this study is student of Pattimura University. Sampling technique using purposive sampling. The type of data used is quantitative data. And the source of data is the primary data obtained from the results of filling questionnaires. To test Hypotheses 1, 2, 3, 4, and 5, used multiple regression analysis tools with SPSS. The regression model used in this study are:

$$
\mathrm{Y}=\mathrm{a}+\beta 1 \mathrm{X} 1+\beta 2 \mathrm{X} 2+\beta 3 \mathrm{X} 3+\beta 4 \mathrm{X} 4+\beta 5 \mathrm{X} 5+\varepsilon
$$

$T$ test is used to test the level of significance of independent variable influence to the dependent variable partially. Decision-making is based on the value of the significance obtained. If the value of p-value $>0.05$ is obtained, it can be concluded that the independent variable individually does not affect the dependent variable, meaning the hypothesis is rejected. Conversely, if obtained value of significance $p$-value $<0.05$, it can be concluded independent variables individually affect the dependent variable, meaning the hypothesis accepted.

\section{Analysis}

\section{Description of Research Results}

In this study, the number of questionnaires distributed amounted to 160 copies, the questionnaire returned as many as 160 copies. So the questionnaires that can be used in this study amounted to 160 copies or 100\%. Characteristics of respondents obtained from the identity of respondents listed on each answer to the questionnaire question. Characteristics of respondents analyzed in this study include characteristics based on gender, age, and entrepreneurial experience (see table 1) 
TANGIBLE : JURNAL AKUNTANSI MULTIPARADIGMA VOL. 5 (2), HAL. 79-86

Table 1. Data of Respondents

\begin{tabular}{|l|l|c|c|}
\hline \multicolumn{1}{|c|}{ Characteristics } & \multicolumn{1}{|c|}{ Categories } & Total & Persentage (\%) \\
\hline Sex & $\bullet$ Male & 43 & $26,88 \%$ \\
& - Female & 117 & $73,12 \%$ \\
\hline Ages & $\bullet<20$ & 109 & $68,13 \%$ \\
& $\bullet 21-25$ & 43 & $26,88 \%$ \\
& $\bullet 26-30$ & 7 & $4,375 \%$ \\
& $\bullet>30$ & 1 & $0,625 \%$ \\
\hline Entrepreneurship experience & $\bullet$ Experience & 36 & $22,5 \%$ \\
& $\circ$ Not Experience & 124 & $77,5 \%$ \\
\hline
\end{tabular}

Source: Primary, 2017 (Data Processed)

\section{Classic assumption test}

Testing of multiple linear regression assumptions aims to avoid the emergence of bias in data analysis and to avoid misspecification of the regression model used in this study. The classical assumption test in this research include normality test, heteroscedasticity test, multicolonierity test and autocorrelation test.

\section{a. Normality test}

Based on the results of computing with the help of IBM SPSS, then generated normal probability plot chart and test results One-Sample Kolmogorov-Smirnov Test as follows:

Figure 2. Normal Probability Plot

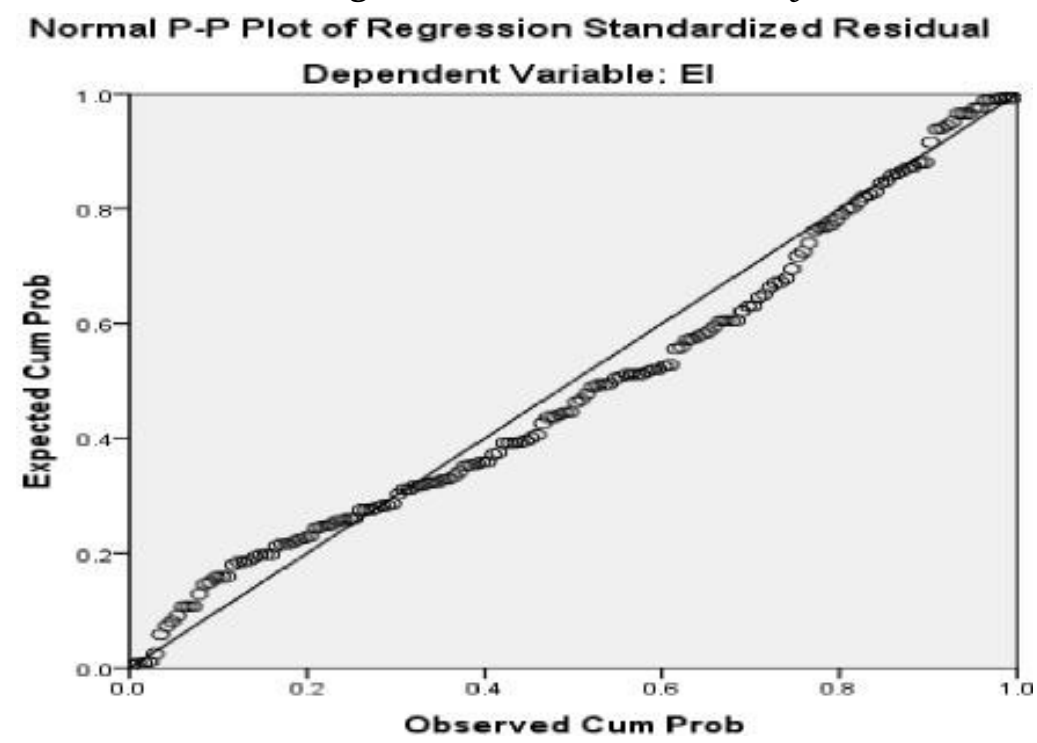

Source: Primary, 2017 (Data Processed)

In Figure 2 Above it can be seen that the spreading points coincide around the diagonal line and direction follow the diagonal line then it can be concluded that the residual data is normally distributed or the data in this study meet the assumption of normality.

\section{b. Heteroscedasticity Test}

The following test results heteroskedastisitas research data. 


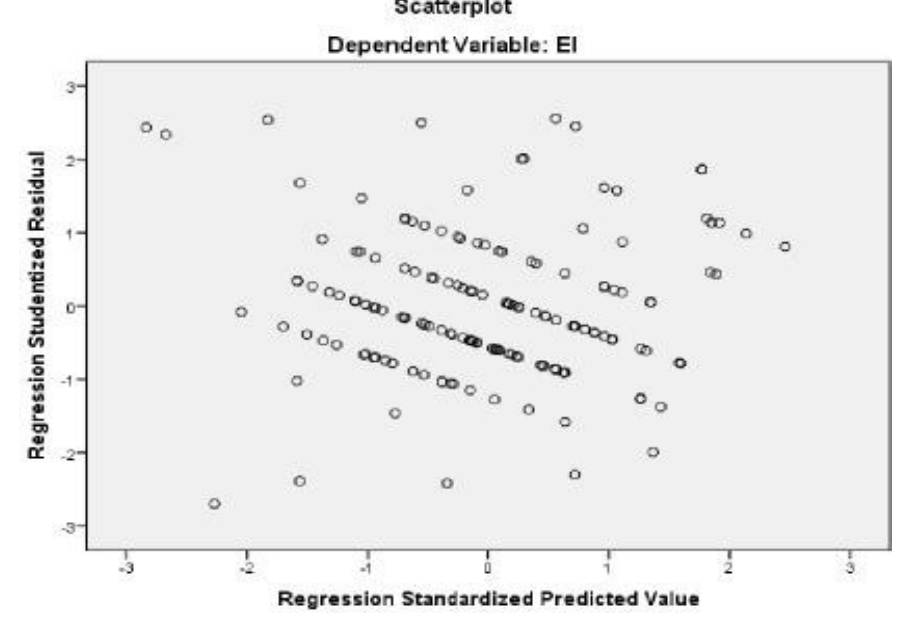

Source: Primary, 2017 (Data Processed)

In the pigure above looks the spots spread above and below the $Y$ axis, there is no particular pattern. Thus it can be concluded that there is no problem of heterokedastisitas in research data and data have fulfilled assumption of heteroskedastisitas.

\section{c. Multicollinearity Test}

The multicollinearity test results can be seen in the table below:

\section{Table 2. Multicollinearity Test Results}

\begin{tabular}{|ll|r|r|}
\hline \multirow{2}{*}{ Model } & \multicolumn{2}{|c|}{ Collinearity } \\
\cline { 3 - 4 } & (Constant) & Tolerance & VIF \\
\hline & NFA & .950 & \\
& LoF & .980 & 1.052 \\
& SE & .020 \\
& .746 & 1.341 \\
& PW & .732 & 1.366 \\
& PW & .952 & 1.050 \\
\hline
\end{tabular}

Source: Primary, 2017 (Data Processed)

The VIF value for the need factor for achievement is 1.052, locus of control is 1.020, self efficacy is 1.341, the readiness of the instrument is 1.366, the entrepreneurial experience is 1.050. Since the VIF value of the five factors is no greater than 10 or 5 , it can be said that there is no multicollinearity in the five independent factors. Based on the classical assumption of linear regression, a good linear regression model is free from multicollinearity. Thus, the above model has been freed from the existence of multicollinearity.

\section{d. Test Autocorrelation}

The following results presented autocorrelation test of research data.

Tabel 3. Autocorrelation Test Results

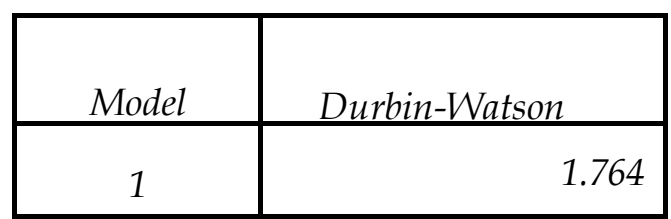

Source: Primary, 2017 (Data Processed) 
TANGIBLE : JURNAL AKUNTANSI MULTIPARADIGMA VOL. 5 (2), HAL. 79-86

The DW score of 1.764 will be compared using the 5\% confidence degree, the sample number 160 and the number of independent variables 5, the DW table will get the value: $d L$ $1.665 d U$ 1.802. Because the DW value is smaller than the upper limit of 1.802 and smaller than $2-d U=2-1.1 .665=0.335$, which means that there is no autocorrelation area. So it can be concluded that in the linear regression model there is no autocorrelation.

\section{Hypothesis Testing}

The following is a description of the results of multiple linear regression testing and test table output using the help of IBM SPSS in the form of output model summary, ANOVA (test $F)$, and coefficient (t test) as can be seen in the table as follows:

Model Summa

\begin{tabular}{|l|r|r|r|r|r|}
\hline Model & $R$ & $R$ Square & Adiusted $R$ & $\begin{array}{c}\text { Std. Error of the } \\
\text { Estimate }\end{array}$ & Durbin- \\
\hline 1 & $.489^{a}$ & .239 & .215 & 1.495 & 1.764 \\
\hline
\end{tabular}

a. Predictors: (Constant), PW, LoF, NFA, SE, IR

Source: Primary, 2017 (Data Processed)

The correlation between the variables of need for achievement, locus of control, self efficacy, instrument readiness, entrepreneurial experience with entrepreneurial intention is 0.489 , with a determination coefficient of 0,215 (adjusted $R$ Square) Thus it can be stated that the intentions of entrepreneurship can be explained by the variable needs will Achievement, locus of control, self efficacy, instrument readiness, Entrepreneurial experience of $21.5 \%$, and the rest influenced by other factors.

Coefficients $^{a}$

\begin{tabular}{|c|c|c|c|c|c|c|c|}
\hline \multirow[b]{2}{*}{ Model } & \multicolumn{2}{|c|}{$\begin{array}{c}\text { Unstandardized } \\
\text { Coefficients }\end{array}$} & \multirow{2}{*}{$\begin{array}{l}\text { Standardize } \\
\frac{d}{\text { Beta }} \\
\end{array}$} & \multirow[b]{2}{*}{$T$} & \multirow[b]{2}{*}{ Sig. } & \multicolumn{2}{|c|}{ Collinearity } \\
\hline & $B$ & Std. & & & & Tolerance & VIF \\
\hline 1 (Constant) & 3.813 & 1.506 & & 2.532 & .012 & & \\
\hline NFA & .067 & .071 & .068 & .942 & .347 & .950 & 1.052 \\
\hline LoF & .066 & .072 & .065 & .916 & .361 & .980 & 1.020 \\
\hline$S E$ & .316 & . 110 & .233 & 2.859 & .005 & .746 & 1.341 \\
\hline$I R$ & .268 & .075 & .294 & 3.579 & .000 & .732 & 1.366 \\
\hline$P W$ & .188 & .319 & .042 & .590 & .556 & .952 & 1.050 \\
\hline
\end{tabular}

a. Dependent Variable: El

Source: Primary, 2017 (Data Processed)

Regression equation:

Intentional entrepreneurship $=3,813+0,067$ (need for achievement) $+(0.066)$ (locus of control) +0.316 (self efficacy) +0.268 (readiness instrument $)+0.188$ (Entrepreneurial experience)

This equation has the following meanings:

Constant of 3,813 means that without the support of variable needs for achievement, locus of control, self efficacy, readiness of the instrument, Entrepreneurial experience, the intention of entrepreneurship students is equal to 3,813. If the variable requirement of achievement will increase will cause an increase of 0,067 on Intelligence entrepreneur intention. If the locus of control variable increases then it will cause a increase of 0.066 on the Intelligence 
TANGIBLE : JURNAL AKUNTANSI MULTIPARADIGMA VOL. 5 (2), HAL. 79-86

Intelligence of students. If the self efficacy variables rise then it will cause an increase of 0.316 at the entrepreneurial intent of students. And if the variable readiness of the instrument increases then it will cause an increase of 0.268 at the Intellection of entrepreneurial students. Meanwhile, if the variables of Entrepreneur Experience increase then it will cause an increase of 0.188 on the Intention of entrepreneurship students. Based on the result of $t$-test on the above Coefficient table it can be seen how far the influence of one partially free variable in explaining the variation of dependent variable. The test results show the influence of the need factor of achievement (X1) on the entrepreneurship intention of student (Y) yields a significance value of 0,347>0,05, which means the factor of need for achievement does not positively and significantly influence the Intelligence entrepreneurial intention of students. Thus, this means $H 1$ is rejected or not proven to have a significant effect.

The $t$-test of the influence of locus of control (X2) on the entrepreneurship intention of student $(Y)$ yields a significance value of $0,361>0,05$, which means the locus of control factor has no positively and significant effect on the entrepreneurship intention of the student of Pattimura University. Thus, this means that $\mathrm{H} 2$ is rejected or not proven to have a significant effect. The self-efficacy effect test (X3) on the entrepreneurship intention of student (Y) yields a significance value of 0,005 $<0,05$, which means self efficacy factor has effect positively and significantly on the entrepreneurship intention of student of Pattimura University. Thus, this means that H3 is accepted and proven to have a significant effect. The t-test influences the readiness of the instrument (X4) on the entrepreneurship intention of student $(Y$ ) yields a significance value of $0,000<0.05$, which means that the readiness factor of the instrument positively and significantly influences the entrepreneurship intention of the students of Pattimura University. Thus, this means H4 is accepted and proven to have a significant effect.

The $t$-test influences entrepreneurial experience (X5) on the entrepreneurship intention of student $(Y)$ yields a significance value of 0,556 >0,05, which means the entrepreneurial experience factor has no positively and significantly influence on the entrepreneurship intention of students of Pattimura University. So, this means H5 is rejected and proved to have no significant effect.

ANOVA ${ }^{a}$

\begin{tabular}{|ll|c|r|r|r|r|}
\hline \multicolumn{2}{|l|}{ Model } & Sum of Squares & Df & Mean Square & F & \multicolumn{1}{c|}{ Siq. } \\
\hline 1 & Regression & 108.218 & 5 & 21.644 & 9.685 & $.000^{b}$ \\
& Residual & 344.157 & 154 & 2.235 & & \\
& Total & 452.375 & 159 & & & \\
\hline
\end{tabular}

a. Dependent Variable: El

b. Predictors: (Constant), PW, LoF, NFA, SE, IR

Source : Primary, 2017 (Data Processed)

Based on ANOVA table it can be seen that the value of F arithmetic is 9.685 with probability value is 0.00 . Because probability value $<0,05$, it can be concluded that the regression coefficient of independent variable simultaneously affect the dependent variable. In other words, the need factor for achievement (X1), locus of control (X2), self efficacy (X3), readiness of instrument (X4), entrepreneurial experience (X5) have positive and significant influence on entrepreneurship intention of student $(Y)$. Based on the results of research known that the need for achievement, locus of control, and Entrepreneurial Experience is not a factor that affects the entrepreneurial intentions among students of Pattimura University. While the Instrumental Readiness and self efficacy, is a factor that affects the entrepreneurial intent of students. The results of this research is similar to the study conducted by Indarti (2004) whose research location at Gadjah Mada University with samples come from various faculties. He found that the self efficacy and readiness of the instrument significantly affected the 
TANGIBLE : JURNAL AKUNTANSI MULTIPARADIGMA VOL. 5 (2), HAL. 79-86

entrepreneurial intent, whereas the locus of control and the need for achievement and work experience had no significant effect on the intention.

But, the results of this study are different from those done by Nurul and Sambharakreshna at Trunojoyo University Madura. Which the results of his research indicate that the need for achievement and self efficacy affect the intentions of student entrepreneurship. And the readiness of the instrument has no effect on the student's entrepreneurial intentions. While the results of research on locus of control factors, experience, showed the same results that there is no significant effect on them.

\section{Conclusion}

Based on statistical analyses above, The conclusions obtain are as follows : Need for achievement do not significantly influence entrepreneurial intention. Locus of control do not significantly influence entrepreneurial intentions, Self-efficacy is significantly influence entrepreneurial intentions, Instrumental readiness is a significant influence of entrepreneurial intentions, and Entrepreneurship experience do not significantly influence of entrepreneurial intentions. Based on the results of research and discussion that has been described in the previous chapter, the authors propose the following suggestions: For Students ; a) It is necessary for students to practice self-control, and self-study to be ready for entrepreneurship at any time. b) It takes practice skills and achievements in applying talents and knowledge so that existing capabilities can be implemented. For University : a) The university should encourage students to participate in the entrepreneurship program so that entrepreneurship interest can be developed, and b) The quality of learning entrepreneurship courses should be more effective for entrepreneurship intentions can be developed.

\section{REFERENCES}

Caecilia Vemmy Susanti. 2012. Factors Affecting the Intent of Entrepreneurship Student Technical Engineering Expertise Program in Tabalong District-South Kalimantan. Journal of Vocational Education.Vol. 2, No. 2.

Ciputra. 2009. Quantum Leap Entrepreneurship; The Future of Your Nation and Your Future (Print to 4). Jakarta: Elex Media Komputindo.

DITJEN Higher Education Kemendibud. 2013. Entrepreneurship Learning Module.

Gorman, G., Hanlon, D., E King, W. 1997. Some research perspectives on entrepreneurship education, enterprise education and education for small business management: a ten-year literature review, International Small Business Journal. 15(3).

Herawati, Nurul dan Sambharakreshna, Yudhanta. 2015. What factors are entrepreneurial intentions of accounting students?. Prosiding Seminar Nasional 4th UNS SME's Summit $\mathcal{E}$ Awards.

Hisrich, Robert D. E Peters, Michael P. 2002. Entrepreneurs (5th ed.).Boston : McGraw-Hill. Indarti, Nurul, 2004. -Factors Affecting Entrepreneurial Intentions Among Indonesian Students.l Jurnal Ekonomi dan Bisnis 19.

Kourilsky, M.L., E Walstad, W. B. (1998). Entrepreneurship and female youth: Knowledge, attitudes, gender differences, and educational practices. Journal of Business Venturing, 13(1).

Suharti, Lieli dan Sirine. 2011. Factors Influencing Entrepreneurship Intent (Entrepreneur Journal), Journal of Management and Entrepreneurship 13 (2).

Suryana. 2006. Entrepreneurship: Practical guide: Tips and processes to success (3rd ed.). Jakarta: Salemba Four. 